\title{
Characteristics of the Ozone pollution and its Health Effects in India
}

\author{
Balajee Karthik L', Babu Sujith', Suliankatchi Rizwan A², Meena Sehgal ${ }^{3}$
}

\section{Balajee Karthik L' ${ }^{1}$, Babu Sujith ${ }^{1}$, Suliankatchi Riz- wan A $^{2}$, Meena Sehgal ${ }^{3}$}

\begin{abstract}
'Department of Preventive and Social Medicine, Jawaharlal Institute of Postgraduate Medical Education and Research (JIPMER), Puducherry, India ${ }^{2}$ Department of Community Medicine, Velammal Medical College Hospital \& Research Institute, Tamil Nadu, India ${ }^{3}$ Centre for Environmental Studies, The Energy and Resources Institute, New Delhi, India
\end{abstract}

*'These authors contributed equally to this work."

\section{Correspondence}

Dr. L. Karthik Balajee

S/o K.Laksham, 33, 6th Cross Street,

Jawahar Nagar, Puducherry, India

Pin: 605005

Ph: 09442037375,09443878088

E-mail: karthikbalajee@ymail.com

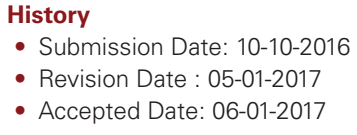

- Accepted Date: 06-01-2017

DOI : 10.5530/ijmedph.2017.1.10

Article Available online

http://www.ijmedph.org/v7/i1

\section{Copyright}

(C) 2017 Phcog.Net. This is an openaccess article distributed under the terms of the Creative Commons Attribution 4.0 International license.

\begin{abstract}
Surface level ozone is one of the important air pollutants. It is formed by the reaction of atmospheric pollutants in the presence of sunlight. The surface ozone shows temporal and spatial variations in the country. The levels are maximum during summer and minimum in monsoon seasons. The levels are maximum during daytime and minimum during night or early morning. In India, surface ozone levels are above the recommended threshold of 8 hour average of $100 \mu \mathrm{g} / \mathrm{m}^{3}$ for air quality monitoring at various stations. Exposure to high levels of surface ozone causes number of health problems. Short term exposure causes drop in lung function measures and it also affects the lung's mucociliary function thereby increasing the susceptibility to bacterial infections. With increase in surface ozone levels, there is likelihood of an increase in risk of hospital admissions for Chronic Obstructive Pulmonary Diseases (COPD) and the number of cardiovascular and respiratory deaths. In children, increase in ozone concentration is associated with increase in hospital admissions and unscheduled asthma medications. The high levels of surface ozone are becoming a threat to people's health and so surface ozone levels have to be monitored and steps taken to reduce their levels.
\end{abstract}

Key words: Surface Ozone, Pollution, Respiratory, Cardiovascular Diseases, India

Key Messages: Surface level ozone is an important air pollutant causing cardiovascular and respiratory diseases. The levels are above the recommended threshold at various stations in India. Surface ozone has to be monitored and steps taken to reduce their levels.

\section{INTRODUCTION}

Outdoor air pollution is a major environmental health problem. Exposure to air pollution leads to increased risk of respiratory diseases like acute respiratory infections and chronic obstructive pulmonary diseases; and cardiovascular diseases, such as stroke and ischemic heart disease. According to World Health Organization, one in eight total global deaths occurs as a result of exposure to air pollution. ${ }^{1}$ Over 3.5 million people die each year from outdoor air pollution. Low- and middle-income countries, especially the Western Pacific and South-East Asian countries account for about $88 \%$ of those premature deaths. ${ }^{1}$ According to a recent study by the Organization for Economic Co-Operation and Development (OECD), in India, the cost of air pollution to society in 2010 was estimated at US\$ 0.5 trillion. ${ }^{2}$ Ozone is one of the air pollutants of major concern globally. Higher levels of ozone in the air can affect human health, leading to breathing problems, asthma exacerbation and reduced lung function. Several studies have also shown that daily mortality and heart diseases increase with exposure to high levels of ozone.

\section{MATERIALS AND METHODS}

Literature search was carried out in PubMed, WHO website and Google Scholar. Inclusion criteria used were: articles published from 1980 to 2014 concerning ozone and its health effects with special reference to India, in any language and of any design. Articles on ozone layer and ozone depletion were excluded. Cross-references of articles included in the review were also searched. Key words used during the search were surface ozone, health effects, air pollution, mortality, morbidity, seasonal variations and ozone standards. All relevant articles were critically analysed and the contents were extracted into broad thematic areas for further interpretation.

\section{RESULTS AND DISCUSSION}

During the search a total of 55 relevant articles were identified and analysed. The results are presented below in the pre-identified thematic areas.

\section{Ozone}

Ozone is a colorless gas composed of three atoms of oxygen. It occurs both in the Earth's upper atmosphere and at ground level. The ozone layer occurs 
naturally in the upper atmosphere (the stratosphere), 6 to 30 miles above the Earth's surface. This protective ozone layer shields the Earth from the sun's ultraviolet rays. But manmade chemicals are gradually destroying this layer, resulting in a "hole in the ozone" over the north and south poles. The tropospheric or ground level ozone lies in the Earth's lower atmosphere is an important photochemical pollutant. This surface ozone $\left(\mathrm{O}_{3}\right)$ is formed when pollutants like as Volatile Organic Compounds (VOCs) and oxides of nitrogen chemically react in the presence of sunlight. As a result, the highest levels of ozone pollution occur during periods of sunny weather. Cars, power plants, industrial boilers, refineries, chemical plants, and other sources emit these pollutants. Once formed, ozone is scavenged by $\mathrm{NO}$ and a "photo stationary state" is formed where concentrations of $\mathrm{NO}, \mathrm{NO}_{2}$ and $\mathrm{O}_{3}$ are all inter-related. But the presence of $\mathrm{CO}$ and VOCs can disturb this steady state relationship by producing peroxy radicals and resulting in an increased ozone concentration. ${ }^{3}$

Due to the worldwide increase in the burning of fossil fuels, atmospheric $\mathrm{CO}_{2}$ concentrations are currently rising at approximately $0.5 \%$ per year and surface ozone values are increasing at a rate of $0.32 \%$ per year. ${ }^{4}$ Ozone can be transported over long distances by wind and due to this even rural areas can experience high ozone levels. High ozone concentrations have also been observed in cold months, with high levels of local VOC and NO emissions. Smog is primarily made up of ground level ozone combined with other gases and particle pollution. Surface ozone is also a greenhouse gas which contributes to climate change.

\section{Characteristics of ozone pollution}

\section{Factors influencing ozone concentration}

Many meteorological factors influence ozone concentration. Solar irradiation and temperature influence the speed and amount of photochemical production of ozone. Vertical temperature gradient influences the vertical mixing in the atmosphere and thereafter the ozone concentration near the ground. Surface winds control the concentrations in mountain valleys and coastal areas. Aloft winds are responsible for the transport of ozone and its precursors. Precipitation decreases the ozone concentration by means of wet deposition. Relative humidity chemically controls the ozone concentration and diurnal meteorological variations cause diurnal variation of ozone concentrations.

\section{Ozone Guidelines}

In 1997, the United States Environmental Protection Agency (EPA) proposed adding an ozone standard of $80 \mathrm{ppb}$ based on the daily 8-hour maximum concentration. WHO Air Quality Guidelines for Europe (WHO AQG, 2000) had set the guideline value for ozone levels at 120 $\mu \mathrm{g} / \mathrm{m}^{3}$ for an 8 -hour daily average. But studies have shown health effects at concentrations below $120 \mu \mathrm{g} / \mathrm{m}^{3}$. So WHO Air Quality Guidelines AQG in 2005 reduced the cut-off from $120 \mu \mathrm{g} / \mathrm{m}^{3}$ to $100 \mu \mathrm{g} / \mathrm{m} 3$ (daily maximum 8-hour mean). ${ }^{5}$ In the year 2009 , for the first time, India included ozone under its Revised National Ambient Air Quality Standards (NAAQS). ${ }^{6}$ According to this, the mean concentration of ozone in ambient air must be less than $100 \mu \mathrm{g} / \mathrm{m}^{3}$ for any 8 hour period of monitoring and less than $180 \mu \mathrm{g} / \mathrm{m}^{3}$ in hourly monitoring. This should be complied with $98 \%$ of the time in a year and in $2 \%$ of the time, they may exceed the limits but not on two consecutive days of monitoring. ${ }^{7}$

\section{Variations in Ozone level}

The ground level ozone levels are not constant. It varies from country to country and even within a country varies from region to region. Monthly measurements at 50 stations in Asia, Africa, South America, and Europe showed that the median ozone concentrations were maximum at Waliguan Mountain, China (45ppb) and minimum at Petit Saut, French Guiana (8ppb). The highest ozone values were found in the mid-latitudes, with Northern hemisphere values exceeding the Southern hemisphere levels, and the lowest values found in the tropical regions. ${ }^{8}$ In India, in addition to regional variation, ozone shows diurnal (or daily) and seasonal variations as shown in Table 1. The ground-level ozone is maximum during summer and minimum during monsoon seasons. In

\section{Table 1: Characteristics of ground level ozone in India}

\begin{tabular}{|c|c|c|}
\hline \multicolumn{2}{|c|}{ Factor } & Stations \\
\hline \multicolumn{3}{|c|}{ Maximum level of Ozone } \\
\hline \multirow{4}{*}{ Season } & Summer & 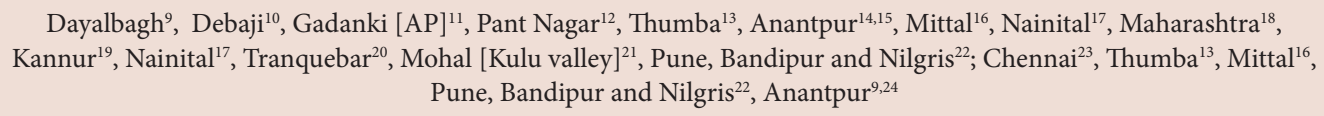 \\
\hline & Winter & 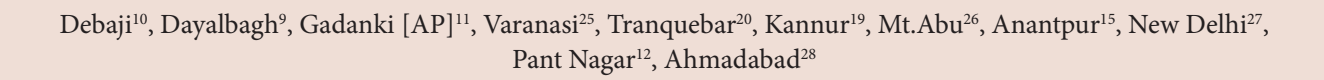 \\
\hline & Autumn & New Delhi ${ }^{27}$, Pant Nagar ${ }^{12}$, Mt. Abu' ${ }^{26}$ \\
\hline & Spring & 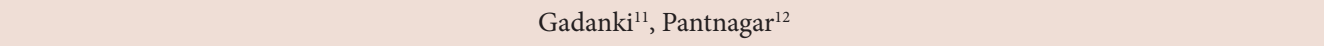 \\
\hline \multirow{3}{*}{ Diurnal } & Noon & $\begin{array}{l}\text { Chandrapur District }{ }^{29}, \text { New Delhi }^{30} \\
\text { Kannur }^{19}, \text { Tranquebar }^{20}, \text { Anantpur }^{29}, \text { Dayalbagh }^{9}\end{array}$ \\
\hline & Evening & Allahabad ${ }^{31}$, Anantpur $^{15}$, Thumba $^{13}$ \\
\hline & Daytime & Anantpur ${ }^{24}$, Pune, Bandipur and Nilgris ${ }^{22}$, Mohal $[\text { Kulu valley }]^{21}$, Dayalbagh ${ }^{9}$, New Delhi ${ }^{27}$, Gadanki ${ }^{11}$, Anatpur ${ }^{32}$ \\
\hline \multicolumn{3}{|c|}{ Minimum level of Ozone } \\
\hline \multirow{3}{*}{ Season } & Monsoon & $\begin{array}{c}\text { Kannur }^{19}, \text { Anantpur }^{24,32}, \text { Varanasi }^{25} \text {, } \\
\text { Pune, Bandipur and Nilgris } \\
22\end{array}$ \\
\hline & Winter & Mohal [Kulu valley] ${ }^{21}$, New Delhi ${ }^{27}$ \\
\hline & Post monsoon & Dayalbagh ${ }^{9}$, Tranquebar $^{20}$ \\
\hline \multirow{3}{*}{ Diurnal } & Morning & Chandrapur District ${ }^{29}$, Kolkata $^{34}$, Anantpur ${ }^{14,15}$, Kannur $^{19}$, Anantpur $^{24}$, Mohal $[\text { Kulu }]^{21}$, Tranquebar $^{20}$ \\
\hline & Night & Kolkata $^{34}$, Kannur $^{19}$, Tranquebar ${ }^{20}$, Dayalbagh ${ }^{9}$ \\
\hline & Evening & Anantpur ${ }^{14,15}$, Anatpur ${ }^{32}$, Mohal $[\text { Kulu }]^{21}$ \\
\hline
\end{tabular}


most parts of the country, the levels are maximum either during daytime or noon and minimum during night time or early morning.

\section{Highest ozone levels in India}

In India, the highest level of ground level ozone has been reported in number of individual studies. But the regional variations of ozone are difficult to document as these studies are done at different stations in varying time points and have used different measures to report the highest level. Still in many locations the 8 hourly ozone levels exceeded the recommended $100 \mu \mathrm{g} / \mathrm{m} 3$ as shown in Table 2 .

\section{Health effects of Ozone: global literature}

\section{Pathological and functional changes in the lung}

Ozone has been shown to alter epithelial permeability of the lung after 18-20 hours of exposure. ${ }^{38}$ The lung's mucociliary function is also acutely stimulated by ozone. ${ }^{39}$ These effects can increase susceptibility to bacterial respiratory infections. Exposure to ambient levels of ozone for 6.6 hours has been shown to increase the markers of inflammation like the Neutrophils (PMNs), Prostaglandin E2 (PGE2), fibronectin, Interleukin-6 (IL-6), and Lactate Dehydrogenase (LDH), alpha-1 antitrypsin in the lungs, and decrease phagocytosis via the complement receptor. ${ }^{40}$ Short-term exposures to ambient-level $\mathrm{O}_{3}$ concentrations cause drop in lung function measures such as lung volume and expiratory flow rates, forced vital capacity and specific airway conductance. ${ }^{41}$ The APHEA (Air Pollution and Health, a European Approach) project in 1997 by Andersen et al in 6 European cities showed there was an increase in hospital admissions for Chronic Obstructive Pulmonary Diseases (COPD ) for all ages for a $50 \mu / \mathrm{m}^{3}$ change in ozone $(\mathrm{RR}=1.04) .{ }^{42}$

Table 2: Highest ozone level recorded at various stations in India

\begin{tabular}{|c|c|}
\hline Location & Level of ozone $\left[\mu \mathrm{g} / \mathrm{m}^{3}\right]$ \\
\hline Chennai $^{23}$ & 106 \\
\hline New Delhi ${ }^{27}$ & $>160^{*}$ \\
\hline Pantnagar $^{12}$ & 100 \\
\hline Ahmedabad ${ }^{28}$ & $<160^{\#}$ \\
\hline Hyderabad $^{35}$ & 198 in 2002 and 180 in 2003 \\
\hline Kolkata $^{34}$ & 96 \\
\hline Chandrapur district ${ }^{29}$ & 50 \\
\hline Pune $e^{36}$ & 120 \\
\hline Anantapur ${ }^{24}$ & $104 \pm 20$ \\
\hline Mt Abu ${ }^{26}$ & $\begin{array}{c}\text { Background }=66 \\
\text { Continental levels }=96\end{array}$ \\
\hline Pune, Bandipur, Nilgiris ${ }^{22}$ & $\begin{array}{c}\text { Annual average }=54 \\
\text { Other Measures }\end{array}$ \\
\hline Anantapur ${ }^{32}$ & Annual average ozone mixing ratio $=35.9$ \\
\hline Anantpur ${ }^{15}$ & Yearly mean mixing ratio $^{\wedge}=35.9 \pm 8.8$ \\
\hline Delhi $^{30}$ & $\begin{array}{l}\text { Threshold exceeded for } 45 \text { days /yr } \\
\text { AOT } 40 \text { index }\end{array}$ \\
\hline $\operatorname{Agra}^{37}$ & $\begin{array}{l}\text { Summer- } 840 \text { ppb.h } \\
\text { Winter- } 2430 \text { ppb.h }\end{array}$ \\
\hline
\end{tabular}

Note:

\#The level of ozone is expressed as $\mu \mathrm{g} / \mathrm{m} 3$ by multiplying ppb by a factor of 2 ${ }^{*}$ Accumulated exposure over a cut-off threshold of $40 \mathrm{ppb}$

$\wedge$ Mixing ratio is defined as the ratio of the number of molecules of a particular trace gas to the number of molecules of all the other gases present in a given volume of air

\section{Mortality}

A meta-analysis of time series studies and panel studies by WHO in 2004 showed that there was a $0.44 \%$ increase in daily mortality per $10 \mathrm{ppb}$ change in 1-hour maximum ozone concentration. ${ }^{43}$ Similarly a metaanalysis of 50 time-series analyses by Levy et al in 2001 showed a $0.39 \%$ change in daily mortality per $10 \mathrm{ppb}$ change in daily 1-hour maximum ozone. ${ }^{44}$ The APHEA project in 15 European cities by Touloumi et al in 1997 showed that increases of $50 \mu \mathrm{g} / \mathrm{m}^{3}$ in $\mathrm{O}_{3}$ (1-hour maximum) was associated with a $2.9 \%$ increase in the daily number of deaths. ${ }^{45}$ The APHEA 2 project by Gryparis et al in 23 cities/areas for 3 years since 1990 showed that an increase in 1-hour ozone concentration by $10 \mu \mathrm{g} / \mathrm{m}^{3}$ was associated with a $0.33 \%$ increase in the daily number of deaths, $0.45 \%$ in the number of cardiovascular deaths, and $1.13 \%$ in the number of respiratory deaths. ${ }^{46}$

\section{Child health}

Young children are sensitive to $\mathrm{O}_{3}$, because significant lung development continues in the postnatal period. ${ }^{47}$ Burnett et al demonstrated that in children under 2 years of age, there was a $6.6 \%$ increase in hospital admissions per $10 \mathrm{ppb}$ change in 1-hour daily maximum ozone $(\mathrm{RR}=1.348) .^{48}$ Thurston et al showed that among children aged 7 to 13 years in summer asthma camps in New York City, an increase in the 1-hour daily maximal ozone concentration from 84 to $160 \mathrm{ppb}$ was associated with increased unscheduled medications administered per day. ${ }^{49}$ The health effects of ozone are summarised in Table 3.

\section{Health effects of Ozone: Indian literature}

Studies on health effects of ozone from India are limited. Gupta et al demonstrated a significant increase in daily hospital admission for respiratory diseases with elevated levels of ozone. ${ }^{50}$ Kumar et al conducted a cross-sectional study in Punjab and showed that levels of ozone were found to be higher in an industrial town than in the a non-industrial town and that residence in the industrial town was associated with increased chronic respiratory symptoms like cough, phlegm, breathlessness, or wheezing $(\mathrm{OR}=1.5)$ and spirometric ventilatory defect $(\mathrm{OR}=2.4) .^{51}$ Jayaraman et al in Delhi showed that a 10-microgram rise in $\mathrm{O}_{3}$ led to increase in respiratory morbidity $(\mathrm{RR}=1.03) .{ }^{52}$

\section{Control of ozone pollution}

Through global climate policies, it is estimated that in the time horizon up to 2050, a decrease of ozone concentrations might save nearly 20,000 cases of premature death per year. ${ }^{53}$ The annual monetary value of health benefits from reducing ozone concentration was estimated to be $\$ 10$ per person per microgram per cubic meter reduction. ${ }^{44}$ Steps that are needed to reduce ground-level ozone are as follows:

\section{Legal framework and monitoring of Ozone levels}

In India, National Air Quality Monitoring Program (NAMP) is a nationwide program executed by Central Pollution Control Board (CPCB) to monitor the ambient air quality through a network of over 340 stations across the country. Under NAMP, only four air pollutants namely Sulphur dioxide (SO2), Oxides of Nitrogen, Suspended Particulate Matter (SPM) and Respirable Particulate Matter (RSPM) are regularly monitored. ${ }^{54}$ Surface ozone is regularly monitored by the CPCB through automatic monitoring stations in New Delhi and few other stations. Nevertheless, surface ozone level must also be regularly monitored throughout the country and particularly in rural neighborhoods surrounding large cities as ozone levels are likely to be high in these neighborhoods, particularly because agriculture production is known to be adversely affected by high ozone concentrations.

Automobile manufacturing and auto fuel industry can introduce several measures to reduce emissions of precursor pollutants including Vapor 
Table 3: Health effects of increased surface ozone

\begin{tabular}{|c|c|c|}
\hline Effects & Experimental Studies & Epidemiological Studies \\
\hline \multirow[t]{5}{*}{ Acute effects } & -Alters epithelial permeability of the lung & -Increase in hospital admissions for COPD \\
\hline & -Stimulates mucociliary function of the lung & -Increase in daily mortality \\
\hline & $\begin{array}{l}\text {-Increase in PMNs, PGE2, LDH, IL-6, alpha1 } \\
\text { antitrypsin, and decrease phagocytosis via }\end{array}$ & $\begin{array}{c}\text {-Increase in the daily number cardiovascular }(0.45 \%) \text { and } \\
\text { respiratory }(1.13 \%) \text { deaths . }\end{array}$ \\
\hline & the complement receptor & -Increase in hospital admissions in children \\
\hline & & -Increased unscheduled asthma medications in children \\
\hline Chronic effects & $\begin{array}{l}\text {-Increased susceptibility to bacterial } \\
\text { respiratory infections }\end{array}$ & \\
\hline
\end{tabular}

Recovery Control, which are systems that control VOC vapour releases during the refuelling of motor vehicles, timely engine turnover, and adoption of cleaner and lower emitting new engines. Similarly, coalburning power plants can adopt clean coal technology to reduce emissions. Urban planners and policy makers can support the cause through improving public transport, reduce congestion on roads, reduce idling time and incentivize use of hybrid or electric vehicles.

To reduce vehicular pollution, Honorable Supreme Court of India has ordered the states to strictly implement Emission Norms and to switch over to clean fuels like Compressed Natural Gas (CNG) and Liquefied Petroleum Gas (LPG). Emission standards for the industries are notified under Environment (Protection Act) 1986 to check pollution. The states have given an action plan to the Supreme Court, in which they have given commitment to monitor that the industries are using cleaner fuel, developing green belt and installing pollution control devices.

\section{Role of individuals and NGOs in controlling Ozone level}

The public can also reduce ozone levels by conserving energy at home and at work; by reducing vehicle by walking, cycling or using public transportation whenever possible, following gasoline-refueling instructions, keeping motor vehicle engines properly tuned and making sure that tires are properly inflated. ${ }^{55}$

\section{CONCLUSIONS}

The ground level ozone measured at various stations across the country exceed the threshold limit. Ground level ozone is a health hazard - leading to respiratory and cardio vascular diseases and their exacerbations and adding to the cost of health care of an already strained health system. Policy changes are required to reduce the generation of ground-level ozone and to monitor the ambient levels and health effects. Further studies have to be conducted to measure the mortality and morbidity due to this pollutant in India and the cost of inaction.

\section{CONFLICT OF INTEREST}

None

\section{REFERENCES}

1. World Health Organization.Burden of disease from ambient air pollution for 2012. [Internet]. Geneva, Public Health, Social and Environmental Determinants of Health Department, World Health Organization, Available from: http:// www.who.int/phe/health_topics/outdoorair/databases/AAP_BoD_results_ March2014.pdf?ua=1

2. OECD (2014), The Cost of Air Pollution: Health Impacts of RoadTransport, OECD Publishing, Paris. Available from: http://dx.doi.org/10.1787/9789264210448-en.

3. Tang L. Regional and Local Surface Ozone Variations in Relation to Meteorological Conditions in Sweden [dissertation on the Internet] Gothenburg, University ofGothenburg, 2009.Availablefrom:https://gupea.ub.gu.se/bitstream/ 2077/20200/1/gupea_2077_20200_1.pdf.
4. Akram A. Ali, Ibrahim A. Hassan and Hanaa S. Fahmi, 2002. Uncertainties in Estimating Ecological Effects of Ozone under Egyptian Climatic Changes . Journal of Biological Sciences, 2: 560-564, Available from: https://doi.org/10.3923/ jbs.2002.560.564.

5. World Health Organization. WHO Air quality guidelines for particulate matter, ozone, nitrogen dioxide and sulfur dioxide: global update 2005: summary of risk assessment. Geneva World Heal Organ [Internet]. 2006;1-22. Available from: http://whqlibdoc.who.int/hq/2006/WHO_SDE_PHE_OEH_06.02_eng.pdf?ua=1.

6. Central Pollution Control Board, National Ambient Air Quality Status 2009, Central Pollution Control Board, Ministry of Environment \& Forests 2011 Available at: http://cpcb.nic.in/upload/Publications/Publication_514airquality status 2009.pdf

7. Central Pollution Control Board, National Ambient Air Quality Status \& Trends In India-2010 Central Pollution Control Board. 2012.

8. Carmichael GR, Ferm M, Thongboonchoo N, Woo JH, Chan LY, Murano K, et al. Measurements of sulfur dioxide, ozone and ammonia concentrations in Asia, Africa, and South America using passive samplers. Atmos Environ. 2003;37 (9-10):1293-308. https://doi.org/10.1016/S1352-2310(02)01009-9.

9. Singla V, Satsangi A, Pachauri T, Lakhani A, Kumari KM. Ozone formation and destruction at a sub-urban site in North Central region of India. Atmos Res. 2011;101(1-2):373-85. https://doi.org/10.1016/j.atmosres.2011.03.011.

10. Debaje SB, Kakade AD. Weekend Ozone Effect over Rural and Urban Site in India. Aerosol Air Qual Res. 2006;6(3):322-33.

11. Naja M, Lal S. Surface ozone and precursor gases at Gadanki $\left(13.5^{\circ} \mathrm{N}, 79.2^{\circ} \mathrm{E}\right)$, a tropical rural site in India. J Geophys Res Atmos [Internet]. 2002 [cited 2015 Feb 1];107(D14):4197.

12. Ojha N, Naja M, Singh KP, Sarangi T, Kumar R, Lal S, et al. Variabilities in ozone at a semi-urban site in the Indo-Gangetic Plain region: Association with the meteorology and regional processes. J Geophys Res Atmos. 2012;117(D20). https://doi.org/10.1029/2012JD017716

13. Nair PR, Chand D, Lal S, Modh KS, Naja M, Parameswaran K, et al. Temporal variations in surface ozone at Thumba $\left(8.6^{\circ} \mathrm{N}, 77^{\circ} \mathrm{E}\right)$-a tropical coastal site in India. Atmospheric Environment. 2002;36(4):603-10. https://doi.org/10.1016/ S1352-2310(01)00527-1.

14. Rama Gopal K, Lingaswamy AP, Arafath SM, Balakrishnaiah G, Pavan Kumari S, Uma Devi K, et al. Seasonal heterogeneity in ozone and its precursors (NOx) by in-situ and model observations on semi-arid station in Anantapur (A.P), South India. Atmos Environ. 2014;84:294-306. https://doi.org/10.1016/ j.atmosenv.2013.10.014

15. Reddy RR, Gopal KR, Reddy LSS, Narasimhulu K, Kumar KR, Ahammed YN et al. Measurements of surface ozone at semi-arid site Anantapur $\left(14.62^{\circ} \mathrm{N}\right.$, $77.65^{\circ} \mathrm{E}, 331 \mathrm{~m}$ asl) in India. J Atmos Chem. 2008;59(1):47-59. https://doi org/10.1007/s10874-008-9094-1.

16. Mittal ML, Hess PG, Jain SL, Arya BC, Sharma C. Surface ozone in the Indian region. Atmospheric Environment. 2007;6572-84. https://doi.org/10.1016/j. atmosenv.2007.04.035.

17. Kumar R, Naja M, Venkataramani S, Wild O. Variations in surface ozone at Nainital: A high-altitude site in the central Himalayas. J Geophys Res [Internet]. 2010 Aug 17 [cited 2015 Feb 1];115(D16):D16302. Available from: http://doi.wiley. com/10.1029/2009JD013715.

18. Debaje SB, Kakade AD. Surface ozone variability over western Maharashtra, India. J Hazard Mater. 2009;161(2-3):686-700. https://doi.org/10.1016/j.jhazmat. 2008.04.010 ; PMid:18486330.

19. Nishanth T, Praseed KM, Kumar MKS, Valsaraj KT. Influence of ozone precursors and PM10 on the variation of surface $\mathrm{O} 3$ over Kannur, India. Atmos Res. 2014;138:112-24. https://doi.org/10.1016/j.atmosres.2013.10.022.

20. Debaje SB, Jeyakumar SJ, Ganesan K, Jadhav DB, Seetaramayya P. Surface ozone measurements at tropical rural coastal station Tranquebar, India. Atmos Environ. 2003;37(35):4911-6. https://doi.org/10.1016/j.atmosenv.2003.08.005.

21. Sharma P, Kuniyal JC, Chand K, Guleria RP, Dhyani PP, Chauhan C. Surface ozone concentration and its behaviour with aerosols in the northwestern Himalaya, India. Atmos Environ. 2013;71:44-53. https://doi.org/10.1016/j. 
atmosenv.2012.12.042.

22. Khemani L. Study of surface ozone behaviour at urban and forested sites in India. Atmospheric Environment. 1995;29(16):2021-4. https://doi.org/10.1016/13522310(94)00293-T.

23. Pulikesi M, Baskaralingam P, Rayudu VN, Elango D, Ramamurthi V, Sivanesan S Surface ozone measurements at urban coastal site Chennai, in India. J Hazard Mater. 2006;137(3):1554-9. https://doi.org/10.1016/j.jhazmat.2006.04.040; PMid:16757111.

24. Reddy BSK, Kumar KR, Balakrishnaiah G, Gopal KR, Reddy RR, Ahammed YN, et al. Observational studies on the variations in surface ozone concentration at Anantapur in southern India. Atmos Res. 2010:98(1):125-39. https://doi. org/10.1016/j.atmosres.2010.06.008.

25. Tiwari S, Rai R, Agrawal M. Annual and seasonal variations in tropospheric ozone concentrations around Varanasi. International Journal of Remote Sensing. 2008; 1;29(15):4499-514

26. Naja M, Lal S, Chand D. Diurnal and seasonal variabilities in surface ozone at a high altitude site $\mathrm{Mt} \mathrm{Abu}\left(24.6^{\circ} \mathrm{N}, 72.7^{\circ} \mathrm{E}, 1680 \mathrm{~m}\right.$ asl) in India. Atmos Environ. 2003:37(30):4205-15. https://doi.org/10.1016/S1352-2310(03)00565-X

27. Jain SL, Arya BC, Kumar A, Ghude SD, Kulkarni PS. Observational study of surface ozone at New Delhi, India. International Journal of Remote Sensing. 2005;3515-24. https://doi.org/10.1080/01431160500076616.

28. Lal S, Naja M, Subbaraya B. Seasonal variations in surface ozone and its precursors over an urban site in India. Atmos Environ [Internet]. 2000 Jan [cited 2015 Feb 1];34(17):2713-24. Available from: http://www.sciencedirect.com/science/ article/pii/S1352231099005105.

29. Salve PR, Satapathy DR, Katpatal YB, Wate SR. Assessing spatial occurrence of ground level ozone around coal mining areas of Chandrapur District, Maharashtra, India. Environ Monit Assess. 2007;133(1-3):87-98. https://doi.org/10.1007/ s10661-006-9562-5. PMid:17286178

30. Ghude SD, Jain SL, Arya BC, Beig G, Ahammed YN, Kumar A, et al. Ozone in ambient air at a tropical megacity, Delhi: Characteristics, trends and cumulative ozone exposure indices. J Atmos Chem. 2008:60(3):237-52. https://doi. org/10.1007/s10874-009-9119-4.

31. Badarinath KVS, Latha KM, Chand TRK, Reddy RR, Gopal KR, Reddy LSS, et al. Black carbon aerosols and gaseous pollutants in an urban area in North India during a fog period. Atmos Res. 2007;85(2):209-16. https://doi.org/10.1016/j. atmosres.2006.12.007.

32. Ahammed YN, Reddy RR, Gopal KR, Narasimhulu K, Basha DB, Reddy LSS, et al. Seasonal variation of the surface ozone and its precursor gases during 2001-2003, measured at Anantapur (14.62 $\left.{ }^{\circ} \mathrm{N}\right)$, a semi-arid site in India. Atmos Res. 2006;80(2-3):151-64. https://doi.org/10.1016/j.atmosres.2005.07.002.

33. Elampari K, Chithambarathanu T, Sharma RK, Jeyakumar SJ. Surface ozone air pollution in Nagercoil, India. Indian Journal of Science and Technology, 2011;4(3):5-8

34. Ghosh D, Lal S, Sarkar U. High nocturnal ozone levels at a surface site in Kolkata, India: Trade-off between meteorology and specific nocturnal chemistry. Urban Clim. 2013;5:82-103. https://doi.org/10.1016/j.uclim.2013.07.002.

35. Chapla J, Jithender S, Naik K, Kamalakar, Baburao N. Ground level ozone concentrations in Hyderabad. Ecol Environ Conserv. 2006;12(1):97-100.

36. Beig G, Ghude SD, Polade SD, Tyagi B. Threshold exceedances and cumulative ozone exposure indices at tropical suburban site. Geophys Res Lett. 2008;35(2). https://doi.org/10.1029/2007GL031434.

37. Satsangi GS, Lakhani A, Kulshrestha PR, Taneja A. Seasonal and diurnal variation of surface ozone and a preliminary analysis of exceedance of its critical levels at a semi-arid site in India. J Atmos Chem. 2004;47(3):271-86. https://doi. org/10.1023/B:JOCH.0000021156.04126.3b

38. Foster WM, Stetkiewicz PT. Regional clearance of solute from the respiratory epithelia: 18-20 h postexposure to ozone. J Appl Physiol [Internet]. 1:81(3):1143-9.

39. Foster WM, Costa DL, Langenback EG. Ozone exposure alters tracheobronchial mucociliary function in humans. J Appl Physiol. 1;63(3):996-1002.

40. Devlin RB, McDonnell WF, Mann R, Becker S, House DE, Schreinemachers D, et al. Exposure of humans to ambient levels of ozone for 6.6 hours causes cellular and biochemical changes in the lung. Am J Respir Cell Mol Biol [Internet]. 1991 Jan [cited 2015 Jan 31];4(1):72-81. Available from: http://www.ncbi.nIm. nih.gov/pubmed/1846079.
41. Kinney PL, Thurston GD, Raizenne M. The effects of ambient ozone on lung function in children: a reanalysis of six summer camp studies. Environ Health Perspect. 1996;104(2):170-174. https://doi.org/10.2307/3432785 : https://doi. org/10.1289/ehp.96104170; PMid:8820584 PMCid:PMC1469279.

42. Andersen HR, Spix C, Medina S, Schouten JP, Castellsague J, Rossi G, et al. Air pollution and daily admissions for chronic obstructive pulmonary disease in 6 European cities: Results from the APHEA project. Eur Respir J. 1997;10:1064-71. https://doi.org/10.1183/09031936.97.10051064

43. Anderson H, Atkinson R, Peacock J, Marston L, Konstantinou K. Meta-analysis of time-series studies and panel studies of particulate matter (PM) and ozone (O3). Rep a WHO Task Gr [Internet]. 2004;1-68. Available from: http://scholar. google.com/scholar?hl=en\&btnG=Search\&q=intitle:Meta-analysis+of+timese ries+studies+and+panel+studies+of+Particulate+Matter+(+PM+)+and+Ozon $\mathrm{e}+(+\mathrm{O}+3+) \# 0$

44. Levy JI, Carrothers TJ, Tuomisto JT, Hammitt JK, Evans JS. Assessing the public health benefits of reduced ozone concentrations. Environ Health Perspect [Internet]. 2001 Dec [cited 2015 Jan 31];109(12):1215-26. Available from: http:// www.pubmedcentral.nih.gov/articlerender.fcgi?artid=1240503\&tool=pmcentr ez\&rendertype=abstract

45. Touloumi G, Katsouyanni K, Zmirou D, Schwartz J, Spix C, de Leon a P, et al. Short-term effects of ambient oxidant exposure on mortality: a combined analysis within the APHEA project. Air Pollution and Health: a European Approach. Am J Epidemiol. 1997;146(2):177-85. https://doi.org/10.1093/oxfordjournals.aje. a009249; PMid:9230780.

46. Gryparis A, Forsberg B, Katsouyanni K, Analitis A, Touloumi G, Schwartz J, et al. Acute effects of ozone on mortality from the "Air Pollution and Health: A European Approach" project. Am J Respir Crit Care Med. 2004;170(30):1080-7. https://doi.org/10.1164/rccm.200403-3330C ; PMid:15282198.

47. Finkelstein JN, Johnston CJ. Enhanced sensitivity of the postnatal lung to environmental insults and oxidant stress. Pediatrics. 2004;113(4):1092-6. PMid:15060204.

48. Burnett RT, Smith-Doiron M, Stieb D, Raizenne ME, Brook JR, Dales RE, et al. Association between ozone and hospitalization for acute respiratory diseases in children less than 2 years of age. Am J Epidemiol. 2001;153(5):444-52. https:// doi.org/10.1093/aje/153.5.444; PMid:11226976.

49. Thurston GD, Lippmann M, Scott MB, Fine JM. Summertime haze air pollution and children with asthma. Am J Respir Crit Care Med [Internet]. American Public Health Association; 1997 Mar 20 [cited 2015 Jan 31];155(2):654-60. Available from: http://www.atsjournals.org/doi/abs/10.1164/ajrccm.155.2.9032209\#. VMz9-ELINv0.

50. Gupta S, Dogra T.D. Air pollution and human health hazards [Internet]. Indian Journal of Occupational and Environmental Medicine. Medknow Publications and Media Pvt. Ltd (B9, Kanara Business Centre, off Link Road, Ghatkopar (E), Mumbai 400 075, India); 2002. p. 89-93. Available from: http://ovidsp. ovid.com/ovidweb.cgi? T $=J S \& P A G E=$ reference $\& D=$ emed5\&NEWS $=N \&$ $\mathrm{AN}=2002329540$

51. Kumar R, Sharma M, Srivastva A, Thakur JS, Jindal SK, Parwana HK. Association of outdoor air pollution with chronic respiratory morbidity in an industrial town in northern India. Arch Environ Health. 2004;59(9):471-7. https://doi. org/10.1080/00039890409603428; PMid:16381489

52. Jayaraman G, Nidhi. Air pollution and associated respiratory morbidity in Delhi. Health Care Manag Sci. 2008;11(2):132-8. https://doi.org/10.1007/s10729-0079050-7 ; PMid:18581819.

53. Rafaj P, Schöpp W, Russ P, Heyes C, Amann M. Co-benefits of post-2012 global climate mitigation policies. Mitig Adapt Strateg Glob Chang. 2013;18(6):801-24. https://doi.org/10.1007/s11027-012-9390-6.

54. Central Polution Control Board,Air/Quality Pollution, NAMP [Internet]. [cited 2015 May 18]. Available from: http://www.cpcb.nic.in/air.php.

55. US EPA. Actions You Can Take to Reduce Air Pollution Ground-level Ozone. New England. US EPA [Internet]. [cited 2015 May 18]. Available from: http://www. epa.gov/region1/airquality/reducepollution.html.

Cite this article : Karthik BL, Sujith B, Rizwan SA, Sehgal M. Characteristics of the Ozone pollution and its health effects in India. Int J Med. Public Health. 2017; 7(1): 56-60. 